\title{
Effects of Bank Insolvency and Strategic Uncertainty on Corporate Restructuring in Transition Economies
}

\author{
By: Christa Hainz
}

William Davidson Working Paper Number 390

August 2001 


\title{
Effects of Bank Insolvency and Strategic Uncertainty on Corporate Restructuring in Transition Economies
}

\author{
Christa Hainz*
}

August 14, 2001

\begin{abstract}
We study the influence of bank insolvency on corporate restructuring in a dynamic model of bank relationship. Using a poorly developed banking technology our model shows that bank insolvency can have a positive effect on firms' incentives to restructure. Due to the technology each firm faces strategic uncertainty on the restructuring decision of other firms. Restructuring has positive externalities on restructuring incentives of other firms which may cause multiple equilibria where either all firms of a generation restructure or no firm restructures. Coordination problems can exist in each period. The optimal extent of coordination policy depends on the restructuring costs.
\end{abstract}

JEL-Classification: D92, G21, G34, 013, P31, P34

Keywords: Transition economies, corporate finance, corporate governance

*Department of Economics, University of Munich, Akademiestr. 1/III, 80799 Munich, Tel.: (49 89) 2180 3232, Fax.: (49 89) 2180 2767, e-mail: christa.hainz@lrz.uni-muenchen.de. The author would like to thank John Bonin, Franz Benstetter, Donata Hoesch, Isabelle Kronawitter, Dalia Marin, Monika Schnitzer, Achim Wambach and seminar participants at the University of Hamburg, the Congress of the European Economic Association 2000 and the CEPR/WDI International Conference in Transition Economics 2001 for helpful comments and suggestions. The usual disclaimer applies. Financial support by the German Science Foundation through grant Schn422/3-1 is gratefully acknowledged. 


\section{Non-technical summary}

We study the influence of bank insolvency on corporate restructuring in a twoperiod model with asymmetric information on the profitability of an investment project. The model consists of a credit market game and a restructuring game. Concerning the credit market game two different types of investment projects are distinguished: they are either profitable or not. Only the firm knows the type; it is not observable to the bank. Naturally, the analysis starts with the credit market. Two generations of firms are asking for credit: the old firms which need credit in both periods and the new firms which enter the credit market in the second period. However, the banking industry is not well developed. There is no screening technology and no distinction whether a potential borrower in the second period is a new firm or an old one which has been rejected by the incumbent bank. Consequently, in the second period the firms are offered a pooling contract which implies that the old firms face a hold-up problem by the incumbent bank as they cannot signal their type to an outside bank. As the firms anticipate this problem they are compensated by a lower interest rate in the first period. Comparative statics show that the second period repayment decreases with a higher degree of bank insolvency.

Next we study the restructuring game. Before firms establish a credit relationship they can undertake costly restructuring which increases the probability that the investment project will be profitable. This decision depends on the expected return of restructuring which is determined by the interest rate. Surprisingly, we find that banking instability has not only a negative but also a positive effect. The positive aspect is that bank insolvency reduces the repayment in the second period and thereby increases the restructuring incentive. The negative influence is on old firms which must pay a higher first period repayment as the banks have to be compensated for the expected loss of future profit if they become insolvent.

We can show that the banking sector establishes an interdependency between the investment decisions. Each manager decides whether to invest in restructuring or not. The payoff of this investment depends on the repayment which is uncertain as the restructuring behavior of the other firms matters. The reason is that only pooling contracts are offered and thus the share of good firms determines the repayment. Therefore a firm has a better incentive to restructure if it is optimistic on the restructuring behavior of all other firms. However, there are costs of restructuring. In this paper we demonstrate that the higher the costs the more complex are the interdependencies between the restructuring decisions of firms of different generations. This implies that with higher costs expectations on the behavior of other firms play an even more influential role for the resulting equilibrium of the restructuring game. If firms are pessimistic about the restruc- 
turing behavior of all other firms, the economy easily ends up in an unfavorable equilibrium, where neither old nor new firms restructure. Therefore coordination policy is desirable to reach the outcome where all firms restructure. Our analysis points out how the restructuring equilibria in different periods are intertwined and provides recommendations on the extent to which coordination policy is needed. 


\section{Introduction}

Firms in transition economies face a higher degree of uncertainty than firms in other countries. First, the economic development of their country is uncertain. Second, there is the fragility of the banking sector. Both factors are of crucial importance for the corporate investment decision as they usually influence the return of the invested funds. Since the process of transition started, banking crises of different intensities occurred in each country in Eastern Europe (Caprio and Klingebiel, 1997). The impact of these bank insolvencies on the real economy is surprising: In many cases bank failure did not trigger "the very severe real-side disruptions typical of other countries" (EBRD, 1998, p. 100). On the contrary, during the banking crises some countries continued growing at about the same pace as other transition countries, e.g. Latvia and the Czech Republic (EBRD, 1998). How can we explain this development? One possible explanation is: "The adverse consequences (for output and growth, C.H.) are likely to be smaller in underdeveloped financial systems that are poorly integrated into the domestic and global economy." (Blommestein, 1997, p. 19).

The impact of bank failure on the corporate sector has so far received little attention in the literature. The only paper in this field is by Gorton and Winton (1998) who argue that instability in the banking sector may be efficient. In their model banks can partially appropriate subsidies from state-owned enterprises which are at the same time less risky borrowers than private entrepreneurs. Thus lending to private entrepreneurs increases the bank's risk to lose its private charter value as it becomes insolvent with a higher probability. The authors conclude that new banks should enter because they tend to lend to (private) firms that do not yet have a lending relationship and - by entering the market - reduce the charter values.

There are two other strands in the theoretical literature which this paper is related to. The first strand is the firm-bank relationship because firms could be influenced by bank failure if they have built up a long-term bank relation. Sharpe (1990) argues that an incumbent bank gains superior information on its customers and therefore has monopoly power on its better-performing customers if twoperiod contingent contracts are not enforceable. This implies that the incumbent banks have more information than outside banks. Dell'Ariccia et al. (1999) show that the resulting adverse selection problem between the banks constitutes a barrier to entry into the banking market.

The second strand is on the strategic uncertainty which each individual firm faces when it decides on investment. A comparable framework in a one-period model with spatial competition is used by Schnitzer (1999b) where the effect of 
bank competition on firm restructuring is studied. Here, the restructuring decision has positive externalities: With more restructuring the investment projects are more profitable. This induces more banks to enter the market. The cost of financing decreases and consequently the restructuring incentive increases. However, multiple equilibria can arise, one with a high number of banks and a high level of restructuring as well as one with a low number of banks and a low level of restructuring.

Our paper differs from the literature described above in important aspects. In contrast to Sharpe (1990) this model is based on an enforceable two-period contract because the hold-up problem is anticipated. Whereas Dell'Ariccia et al. (1999) study market entry into the banking sector we focus on the exit of banks since this phenomenon is typical for transition countries. In Schnitzer (1999b) the interdependency between the firm's restructuring decision is caused by the market entry decision of banks. However, this modelling of an interdependency seems rather complicated as it also arises if banks offer pooling contracts. In this paper it is argued that pooling reflects the poor banking technology because banks cannot screen efficiently and do not have information on the credit history of new applicants. Through the pooling contract the repayment is determined by the average quality of firms which causes the interdependency between the restructuring decisions and thus a coordination problem.

Gorton and Winton (1998) can explain the positive effect of bank insolvency on the corporate sector. However, they base their analysis on a model with different types of banks and firms. Rather than studying the incentive structures of different types of agents this paper focuses on the effects of informational asymmetries which are very severe in transition economies. We argue that banks are empirically the most important financial intermediaries, but they do not perform all the tasks they are supposed to, i.e. evaluating credit risks and processing information. To analyze the influence of bank insolvency on corporate restructuring we study a two-period model in which firms decide in each period whether to restructure or not. Two generations of firms are applying for credit: the old firms which need credit in both periods and the new firms which enter the credit market in the second period. Due to the banking technology the firms are offered a pooling contract in each period. This implies that the old firms face a hold-up problem by the incumbent bank in the second period. As the firms anticipate this problem they are compensated by a lower interest rate in the first period.

Since the restructuring decisions are interdependent, firms have a better incentive to restructure if they expect that the other firms - in the same or the next period - restructure, too. The strategic uncertainty on the restructuring decision of other firms is transmitted by the banking system, i.e. through the pooling contracts. Therefore bank insolvency influences the corporate investment 
decision. The interdependency of decisions becomes more complex as the restructuring costs increase. Our model gives detailed policy implications to which extent coordination is necessary to reach the efficient level of restructuring.

This paper continues as follows. In Section 2 a dynamic model of the credit market is presented. In Section 3 we study the effect of strategic uncertainty on the firms' restructuring behavior, characterize the resulting equilibria and conclude with recommendations for coordination policy. The effects of bank insolvency on corporate restructuring are analyzed in Section 4. In Section 5 we conclude with a discussion of the assumptions of the model, the main results and its implications for transition economies.

\section{A two-period model of the credit market}

\subsection{The model}

In this paper we study the influence of bank insolvency on corporate restructuring. For this purpose, we first develop a two-period model of the credit market where two types of firms interact. There are firms which are active in the credit market for both periods and others which enter the credit market in the second period. They will be called old and new firms. The total number of firms is normalized to 1 . It is assumed that in the first period a share of $\mu(0<\mu<1)$ firms and in the second period a share of $(1-\mu)$ enter the market. We set $\mu=0.5$ to keep the analysis as simple as possible. Firms have two different types of investment projects: projects with a payoff $X$ and projects with a payoff of 0 . The investment project costs $I$, independent of its type. As it is only efficient to undertake projects with payoff of $X$ they are labeled "good", whereas the others are "bad". The projects have to be credit financed as the firms have no own funds. There are $p$ good firms among the old firms, which enter the credit market in period 1 , and $q$ good firms among the new firms, which enter the credit market in period 2. We assume that the investment projects are identical in period 1 and 2. Furthermore, from a social welfare point of view it is efficient to undertake credit financed investment as $p X-I>0$ and $q X-I>0$.

Now the information structure is outlined. The probability distribution of good and bad firms in each period ( $p$ and $q$ ) is observable for the banks before they grant credit. The share of good firms is determined by the restructuring decision which is made by the old (new) firms before period 1 (2). However, the banks cannot efficiently screen the projects ex ante and therefore offer a pooling contract to all borrowers. ${ }^{1}$ We assume that a firm can get credit from only one

\footnotetext{
1 "As some of the banking skills (e.g., credit analysis and liquidity and risk management)
} 
bank. During the first period relationship the incumbent bank learns the type of the borrower because it gets information on the firm's business, e.g. by observing the transactions on the firm's account. In this model it receives a perfect signal on the creditworthiness. But the incumbent bank cannot credibly communicate this information to other banks. Furthermore, these outside banks do not know whether a firm is old or new when the firm applies for credit in the second period. The assumption concerning screening and the intertemporal spill-over of information might seem strong. They are chosen in this way in order to render the analysis as clear as possible. After the results of the model with the strong assumptions are presented it will be shown that a relaxation of the assumptions does not change the nature of the effects but reduces their seize.

There are $N$ banks in the banking sector which compete in Bertrand fashion. They have sufficient funds to finance all projects. In the Introduction we have seen that insolvency of banks is a characteristic feature in transition countries. We assume that there is a proportion $w$ of banks which stay in the market and a proportion $(1-w)$ of banks which become insolvent at the end of period 1 . Thus $w$ characterizes the degree of solvency of the whole banking sector. The proportion of banks that fail is exogenous. This can be justified by the empirical evidence which shows that there are many reasons why banks get into trouble which cannot (fully) be influenced by the banks themselves. ${ }^{2}$ Neither the banks nor the firms know which banks will have to declare bankruptcy before they sign the contract. At the time when credit is negotiated it is not observable for the competing banks which incumbent bank became insolvent. ${ }^{3}$

required in a free-market environment must be learned partly by trial and error, some of the resulting mistakes were unavoidable." (Hansson and Tombak, 1999, p. 218).

${ }^{2}$ Two examples are: The minimal capital requirements have been increased by the regulatory bodies several times. However, some banks were not able to fulfill the new requirements, but only some of them had to leave the market. In the Baltics the sudden removal of government deposits occasionally caused short-term liquidity problems (Hansson and Tombak, 1999).

${ }^{3}$ This assumption might seem very strong. What we want to capture is that banks face shocks which can reduce their capacity to prolong credit to old firms. However, different lending capacities have important implications for the market structure in the second period. They are studied in Dell'Ariccia et al. (1999). As we want to focus on the effects of the poor banking technology we use this simplifying assumption. 
The time structure is illustrated in the following figure:

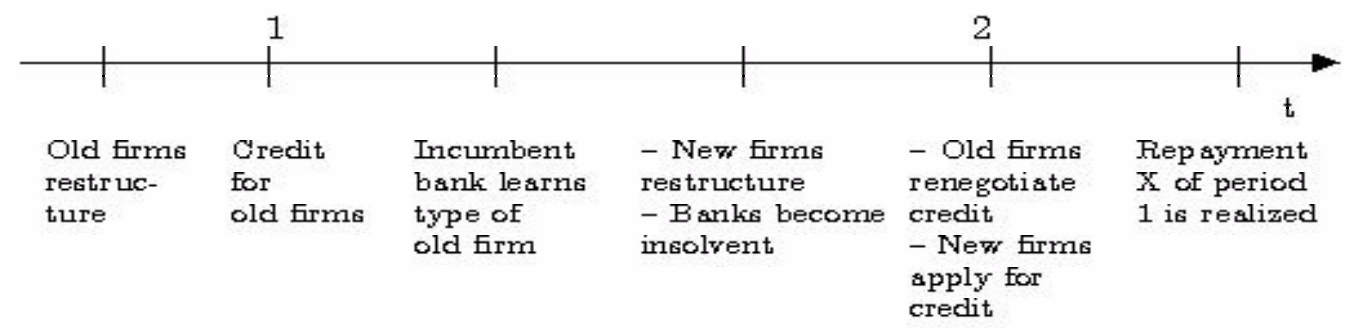

Figure 2.1: Time structure

\subsection{Costs of financing}

As described in the figure, credit is granted in the beginning of each period. In the first period all banks simultaneously announce the interest rate for the old borrowers. In the second period we assume that banks have two sequential moves. In the beginning of the first period they simultaneously choose the interest rate for newly applying customers. Then they determine an interest rate for their old customers. Firms move last. Old firms decide whether to pretend to be a new firm. They choose the lowest offer and we assume that an old firm continues to lend from the incumbent bank if it is indifferent between the offers of incumbent and outside banks. The game is solved by backward induction. We first characterize the equilibrium when banks are offering a credit contract to their old customers. Then we analyze the interest rate which is demanded from unknown firms when they apply for credit in period 2. Finally, we study the interest rate which the bank offers to old firms in period 1. Solving the game the following proposition concerning the interest rate is obtained:

Proposition 1. In period 2 all firms pay the same interest rate, i.e. $R^{2}=$ $I \frac{1-\mu p w}{(1-\mu) q+(1-w) \mu p}$.

\section{Proof:}

See Appendix.

The incumbent bank $g$ learns the type of a firm during the first period lending relationship. The bank is willing to grant credit to good old firms only, as it is not efficient to finance a bad firm. As good old firms cannot credibly signal their type in period 2, they face a hold-up problem by the incumbent bank $g$ which 
demands a repayment that is higher than the fair repayment $I$. In equilibrium the incumbent bank demands the same as the outside bank, i.e. $R^{2 g}=R^{2}$, the good old firm is indifferent between the incumbent bank and its competitors, and the firm does not switch banks.

In period 2 there are firms which do not receive credit from their incumbent bank - either because the incumbent bank became insolvent or because it is unwilling to lend to bad firms. These firms do not signal to be an old firm because an outside bank offers them a contract with a lower repayment if they pretend to be a new firm and are pooled with the new firms. As banks engage in price competition for newly applying firms and firms randomly choose a bank when the offers are equal, we get the standard result of Bertrand competition with homogeneous goods: All banks demand the same interest rate and make zero profit. Accordingly, the average creditworthiness of the applying firms determines the equilibrium interest rate. The pool of new applicants consists of all new firms, the old firms from insolvent banks and the bad old firms from the solvent banks. Bank $h$ demands an interest rate of $R^{2 h}$ in period 2, which is determined by its breakeven condition where the costs of raising funds are normalized to zero:

$$
\frac{1}{N}\left((1-\mu)\left(q R^{2 h}-I\right)+\mu\left((1-w)\left(p R^{2 h}-I\right)+w(1-p)(-I)\right)\right)=0
$$

The banks need an interest rate of $R^{2}=I \frac{1-\mu p w}{(1-\mu) q+(1-w) \mu p}$ to make an expected profit of zero. We assume that $X \geq R^{2}$ for $\forall p, q, w$ and that $R^{2}>\frac{I}{p}{ }^{4}$

Comparative statics show that $R^{2}$ increases with $w$, the degree of solvency. For a lower degree of bank solvency this means: If banks fail, the share of good old firms applying for credit in the second period increases, the average quality of debtors increases and thus the repayment, which is necessary for the bank to break even, decreases.

\footnotetext{
${ }^{4}$ This first assumption rules out credit rationing. Stiglitz and Weiss (1981) show that interest rates influence the quality of the population of firms which is applying for credit. Since our model features only two different risk types there are two boundary solutions. Either all firms receive credit or no firm receives credit in the second period. Due to this simple framework the effect of credit rationing is not further investigated.

The parameter constellations which we refer to for the second assumption are studied in detail in Proposition 4. The second assumption $R^{2}>\frac{I}{p}$ is fulfilled for all parameter constellations despite $(\underline{p}, \bar{q})$. However, the strategy where old firms do not restructure $(\underline{p})$ but new firms restructure $(\bar{q})$ is not chosen in equilibrium in the two period game. This assumption would imply: $(\bar{q}-p)-w p(1-p)<0$. As there are more good new firms than good old firms the first term is positive. Due to this assumption the negative effect that bad old firms "reapply" in the second period overcompensates the positive effect which a higher share of good new firms has on repayment.
} 
What are the effects if the assumption concerning screening and intertemporal spill-over of information are relaxed? First, let the banks have the ability to screen the firms in an efficient manner. It is plausible to assume that the screening technology is not perfect. This means that part of the good firms are denied credit because of a wrong screening result. Furthermore, part of the bad firms receive credit because the result of the screening process is wrong. What is the population of firms like which receive credit in the second period? There are the new firms which are screened as good. From the old firms those with an insolvent bank apply at an outside bank and those of them which are screened as good receive credit - good ones as well as bad ones. Furthermore, bad old firms from solvent banks apply for credit again. And some of them receive credit as the screening technology is imperfect. Thus compared to the analysis above the quality of firms which receive credit increases and the good firms have to finance only a smaller share of bad firms. However, the basic problem that the firms are pooled together and that the quality of old firms which apply for credit in the second period depends on the degree of bank insolvency remains the same.

Second, assume that the credit history of old firms is observable in the second period but information is not perfect. This is captured as follows: information on the good old firms is perfect. However, a share of the bad old firms does not have a negative entry in their credit history. This means that all those bad old firms which have the negative entry in their credit history are denied credit. The others which do not have an entry can either pretend to be good or pretend to be a new firm. Which strategy they choose depends on the difference in repayments for old and new firms. In case of intertemporal information spill-over there is more information on the old firms than on the new firms and this fact might give the old firms an incentive to announce that they are old because then they are not pooled together with new firms where the banks have less information on the quality of an individual firm. But the old firms are still pooled together and there is a fraction of bad old firms among them. Due to this fact the degree of bank insolvency matters: the less banks become insolvent the less good firms apply at an outside firm and the higher has to be the repayment. These arguments have shown that even with imperfect screening and intertemporal spill-over of information pooling still takes place and therefore the average quality of firms as well as the degree of bank insolvency plays an important role.

Now we continue with the first period and study how the repayment $R^{1}$ is determined.

Proposition 2. In period 1 old firms are compensated for the hold-up problem they face in period 2, i.e. $R^{1}=\frac{I}{p}-w \delta^{B}\left(R^{2}-I\right)$. 


\section{Proof:}

See Appendix.

The hold-up problem in period 2 is anticipated in period 1 . The incumbent bank makes zero profit out of this two-period relationship with good old borrowers, where the bank's payoff in period 2 is weighted with the discount factor $\delta^{B}$. Thus $R^{1}<\frac{I}{p}$, where $\frac{I}{p}$ is the repayment necessary for a bank to make zero profit in expectations in period 1. $\frac{I}{p}$ is reduced by the net present value of the profit which the incumbent bank makes with its old customers in period 2. The higher the degree of solvency in the banking sector $w$, the lower is $R^{1}$. This result is due to two effects. First, increasing $w$ increases the repayment in period 2 and therefore the discount in period 1 has to be higher. Second, with a higher $w$ an individual bank survives with a higher probability and thus a lower first period repayment is enough to make zero profit in this two-period relationship.

\section{Strategic uncertainty and corporate restructuring}

So far the equilibrium interest rates on the credit market have been derived. What we want to study in this paper is the influence of the credit market and especially the influence of bank insolvency on corporate restructuring. For this purpose we have to model the investment decision. Each manager of a new firm can influence the quality of the project, which he is going to undertake, before he actually invests $I^{.}{ }^{5}$ The costs associated with restructuring consist of the restructuring effort of the manager as well as other costs. If an old firm, which enters the credit market in the first period, invests $K$ in restructuring, the probability for the investment project to turn out good rises from $\underline{p}$ to $\bar{p}$. For a new firm, which enters the credit market in the second period, investing $C$ raises the probability for a good project from $q$ to $\bar{q}$. For simplicity we set $\bar{p}=\bar{q}$ and $p=q$. Moreover, the restructuring of an old firm influences the type of the firm's investment project not only in the first but also in the second period. As there is a large number of firms the probability for an individual firm that a project turns out to be good is equal to the share of good firms in the firm population.

The restructuring game is solved by backward induction. First the restructuring decision of new firms is studied (4.1). Then it is analyzed how the old firms restructure (4.2). As an old firm's restructuring decision depends on the expectation on the behavior of all other firms, there are important interactions between the restructuring games in the first and the second period. The results of the two-period game will be characterized together (4.3). Next, policy impli-

\footnotetext{
${ }^{5}$ In the transition context firms can decide to restructure before the investment project starts.
} 
cations are derived (4.4). Finally, the impact of bank insolvency on corporate restructuring is analyzed (4.5).

\subsection{New firms}

It is efficient for each manager of a new firm, which enters the credit market in the second period, to invest in restructuring which costs $C$ if: ${ }^{6}$

$$
\bar{q}_{j}\left(X-R^{2}(p, q)\right)-C \geq \underline{q}_{j}\left(X-R^{2}(p, q)\right)
$$

The payoff of a good project is determined by the profit $X$ and the interest rate $R^{2}(p, q)$, which depends on the share of good firms among the new firms $(q)$ and among the old firms $(p)$ where $p$ is given and observable. For notational simplification define $\Delta q=\bar{q}_{j}-\underline{q}_{j}$. Before the result of the restructuring decision is shown, we have to inspect the repayment in the second period $R^{2}(p, q)$ more closely. The repayment is determined by the distribution of good and bad firms in the population of old and new firms. As the individual firm is small, its own restructuring decision has no influence on the size of $R^{2}(p, q)$. The following lemma shows the ranking of the cost boundaries:

Lemma 1. A change in the share of good new firms has a stronger impact on the interest rate $R^{2}(p, q)$ than a change in the share of good old firms, i.e. $R_{1}^{2}(\bar{p}, \bar{q})<$ $R_{2}^{2}(\underline{p}, \bar{q})<R_{3}^{2}(\bar{p}, \underline{q})<R_{4}^{2}(\underline{p}, \underline{q})$.

Proof:

See Appendix.

The intuition for this result is that in period 2 all new firms apply for credit at a bank which does not know their type. Among the old firms, we have to differentiate depending on whether the incumbent bank survives or not. Good as well as bad old firms apply again in the second period if their incumbent bank went bust. However, if the incumbent bank still operates, only bad old firms apply at outside banks. Hence, a change in the share of good firms among the new firms as well as among the old firms which were financed by an insolvent bank has a higher impact on repayment. In these cases the number of good firms, which apply in the second period, increases and the number of bad firms decreases. In contrast, an increase in the share of good old firms with a solvent incumbent bank influences the pool of newly applying firms in period 2 only once by reducing the

\footnotetext{
${ }^{6}$ The expression "restructuring" should be interpreted as every effort which increases the likelihood that the project turns out to be good. For transition economies this effort could be made to restructure existing firms which undertake a new investment project in period 2 .
} 
number of bad firms. The result is that a change in the share of good new firms has a stronger impact on the interest rate $R^{2}(p, q)$ than a change in the share of good old firms.

The restructuring decisions of the managers of new firms depend on the costs of restructuring as well as on the restructuring decisions of the old firms and of all other new firms. To study these effects we define different boundaries where the decision to restructure might change. The definition is

$$
\Delta q_{j}\left(X-R_{l}^{2}(p, q)\right)=C_{l}(p, q)
$$

$l=1,2,3,4$ describes all combinations of $\bar{p}, \underline{p}, \bar{q}, \underline{q}$.

Proposition 3. (1) If restructuring costs are low, i.e. $C \leq C_{4}(\underline{p}, \underline{q})$, there exists a unique equilibrium where all new firms restructure. In period $2 \bar{q}$ good new firms enter.

(2) If restructuring costs are intermediate, i.e. $C_{4}(\underline{p}, \underline{q})<C \leq C_{1}(\bar{p}, \bar{q})$, there exist two pure strategy equilibria:

(EQ1) all new firms restructure

(EQ2) no new firm restructures.

In (EQ1) $\bar{q}$ good new firms enter in period 2, in (EQ2) q good new firms enter.

(3) If restructuring costs are high, i.e. $C_{1}(\bar{p}, \bar{q})<C$, there exists a unique equilibrium where no new firm restructures. In period $2 \underline{q}$ good new firms enter.

\section{Proof:}

See Appendix.

Proposition 3 shows that the restructuring decision of a new firm depends on the costs of restructuring. If costs are low, restructuring is attractive for all firms, independent of the restructuring decision of other firms. For high costs it is never efficient to restructure. However, in the intermediate range of $C$, the outcome depends on the restructuring decision of the other new firms as well as on that of the old firms. The share of good old firms is observable for the new firms. For the top and the bottom end of the intermediate cost range $\left(C_{4}(\underline{p}, \underline{q})<C \leq C_{3}(\bar{p}, \underline{q})\right.$ and $C_{2}(\underline{p}, \bar{q})<C \leq C_{1}(\bar{p}, \bar{q})$, for details see Appendix) the new firms will restructure only if the old firms have decided to restructure. Thus our model allows us to explain a path-dependent development where the initial starting conditions determine the further development. Only if an economy starts from a situation with a high share of good firms, a positive development with restructuring follows. In contrast, if the share of good firms is low which should be 
interpreted as poor starting conditions, the future development is characterized by a lack of restructuring and thus a low share of good firms. ${ }^{7}$

In the middle and at the top end of the intermediate cost range $\left(C_{3}(\bar{p}, \underline{q})<\right.$ $\left.C \leq C_{1}(\bar{p}, \bar{q})\right)$ the restructuring decision of each manager depends on the action of the other new firms. The reason for this coordination problem is that the decision of each firm manager depends on the expected payoff of the project, i.e. profit net of repayment, where the repayment $R^{2}$ is influenced by the restructuring decision of all other new firms. ${ }^{8}$ Each firm restructures only if it is optimistic on the restructuring behavior of all other firms. To avoid the equilibrium without restructuring some coordination might be needed.

The proposition shows that the decision of old firms to restructure has a positive impact on the restructuring behavior of the new firms. We will now study the interaction in more detail.

\subsection{Old firms}

The analysis so far was focused on the restructuring behavior of the new firms in period 2. Now we study the behavior of old firms, which enter the credit market in the first period and restructure before period 1. Through their restructuring decision the old firms influence the probability that the project is good. After the type of the project is revealed to the firm, it stays the same for both periods. Each manager of an old firm compares the payoff when incurring costs of $K$ with the payoff without restructuring. The payoff in period 2 has to be discounted with $\delta^{F}$, the discount factor of the firm, where $\delta^{F} \geq \delta^{B}$. The banks' discount factor should be lower $\left(\delta^{F}>\delta^{B}\right)$ if banks face an upper limit for their losses in period 1. The reason is that the expected profit from old firms in period 1 is negative and therefore banks could be forced to limit these losses by demanding a higher repayment in the first period. The manager of an old firm decides to restructure if:

$$
\begin{aligned}
& \bar{p}_{i}\left(\left(X-R^{1}\right)+\delta^{F}\left(w\left(X-R^{2 g}\right)+(1-w)\left(X-R^{2}\right)\right)\right)-K \\
\geq & \underline{p}_{i}\left(\left(X-R^{1}\right)+\delta^{F}\left(w\left(X-R^{2 g}\right)+(1-w)\left(X-R^{2}\right)\right)\right)
\end{aligned}
$$

The total expected payoff of restructuring is determined by the profit $X$ and the repayments in both periods. From Section 3.2 we know that $R^{1}$ depends on

\footnotetext{
${ }^{7}$ Another argument for a path-dependent development is made by Ickes and Ryterman (1994). They argue that the decisions made by state-owned enterprises in the initial period of transition crucially determine their future developmental possibilities.

${ }^{8}$ For $C^{2}(\underline{p}, \bar{q})<C \leq C^{1}(\bar{p}, \bar{q})$ both, the restructuring behavior of old and new firms, are relevant for firm $j$ 's decision. Thus, the coordination problem among the new firms arises only if the old firms have restructured.
} 
$R^{2}$ and $R^{2 g}=R^{2}$. Thus we can rearrange the returns of restructuring

$$
\Delta p_{i}\left(X-\frac{I}{p}+\delta^{B} w\left(R^{2}(p, q)-I\right)+\delta^{F}\left(X-R^{2}(p, q)\right)\right) \geq K
$$

As for the new firms, there is strategic uncertainty for the old firms on the restructuring behavior of the other firms. Furthermore, the manager of an old firm has to take into account that the restructuring decision of all old firms might influence the restructuring decision of new firms. Thus, the two-period restructuring game has to be solved by backward induction. In Proposition 3 we have already characterized the best responses of the new firms. The way in which the old firm's decision influences the new firm's decision depends on the relationship between restructuring costs in period 1 and 2. To compare these costs we first have to inspect the benefits and costs of restructuring in period 1 in more detail.

The restructuring decision of old firms influences the payoff characteristics of the project for two periods. Therefore it is plausible to assume that this long-term restructuring causes higher expenses. To make the decisions of old and new firms comparable, we define $K \equiv(1+f) C$ with $f>0$. At the same time, the average return (per period) of a two-period investment (old firm) should be at least as high as that of a one-period investment (new firm). This is due to the fact that the repayment in the second period is higher than in the first period as

$$
R^{1}-R^{2}=\left(\frac{I}{p}-R^{2}\right)-\delta^{B} w\left(R^{2}-I\right)<0
$$

We have shown that the return of restructuring depends on the repayment in both periods. To derive the reaction functions of the old firm, we define the different boundaries where the restructuring decision of the old firm might change.

$$
\begin{aligned}
& \Delta p_{i}\left(X-\frac{I}{p}+\delta^{B} w\left(R^{2}(p, q)-I\right)+\delta^{F}\left(X-R^{2}(p, q)\right)\right) \\
= & K_{l}(p, q)=(1+f) C_{l}(p, q)
\end{aligned}
$$

$l=1,2,3,4$ describes all combinations of $\bar{p}, \underline{p}, \bar{q}, \underline{q}$. When comparing the different boundaries the following ranking obtains.

Lemma 2. The cost boundaries for the restructuring decision of an old firm are influenced more strongly by the restructuring decision of old firms than of new firms, i.e. $K_{4}(\underline{p}, \underline{q})<K_{2}(\underline{p}, \bar{q})<K_{3}(\bar{p}, \underline{q})<K_{1}(\bar{p}, \bar{q})$. 


\section{Proof:}

See Appendix.

The intuition for this result is that the share of good old firms influences the repayment in two periods. The share of good new firms fully matters in the second period, but influences the repayment in the first period only to a limited extent. Therefore, the share of good firms in the own generation has a higher impact on the sum of repayments. This Lemma is important for determining the subgame perfect equilibria of the whole restructuring game.

\subsection{Interdependency of restructuring decisions}

The costs and benefits of restructuring of old firms and of new firms have been studied in Section 4.2 and 4.1 respectively. Depending on the size of $f$, which determines how much higher the restructuring costs are in the first period compared to the second period, different interdependencies can be observed between the restructuring behavior of old and new firms. The restructuring decision of old firms depends on the costs of restructuring as well as on the restructuring decisions of all other old firms and of the new firms. The same holds for the new firms. In the following proposition we characterize all possible subgame perfect equilibria at the highest level of interdependency of restructuring decisions. ${ }^{9}$

Proposition 4. (1) If restructuring costs are very low, i.e. $C \leq \frac{K_{4}(\underline{p}, \underline{q})}{1+f}$, there exists a unique subgame perfect equilibrium where all old and new firms restructure (EQ1).

(2) If restructuring costs are low, i.e. $\frac{K_{4}(\underline{p}, \underline{q})}{1+f}<C \leq C_{3}(\bar{p}, \underline{q})$, at the bottom end or at the middle of the intermediate cost range, i.e. $C_{3}(\bar{p}, \underline{q})<C \leq$ $C_{2}(\underline{p}, \bar{q})$ or $C_{2}(\underline{p}, \bar{q})<C \leq \frac{K_{2}(\underline{p}, \bar{q})}{1+f}$, or high, i.e. $\frac{K_{3}(\bar{p}, \underline{q})}{1+f}<C \leq C_{1}(\bar{p}, \bar{q})$, there exist two pure strategy subgame perfect equilibria:

(EQ1) all old and new firms restructure

(EQ2) neither old nor new firms restructure.

(3) If restructuring costs are at the top end of the intermediate range, i.e. $\frac{K_{2}(\underline{p}, \bar{q})}{1+f}<C \leq \frac{K_{3}(\bar{p}, \underline{q})}{1+f}$, there exist three pure strategy subgame perfect equilibria: (EQ1) all old and new firms restructure

(EQ2) neither old nor new firms restructure

\footnotetext{
${ }^{9}$ There are fewer multiple equilibria if there are fewer interactions between the restructuring decisions. An additional unique subgame perfect equilibrium can be found where old firms restructure but new firms do not restructure. This is also part of the additional multiple equilibria, where it is either combined with an equilibrium where old as well as new firms restructure or with an equilibrium where neither old nor new firms restructure.
} 
(EQ3) old firms restructure, but new firms do not restructure.

(4) If restructuring costs are very high, i.e. $C_{1}(\bar{p}, \bar{q})<C$, there exists a unique subgame perfect equilibrium where neither old nor new firms restructure.

In period $1 \bar{p}$ good old firms enter if all old firms restructure. Otherwise there are $\underline{p}$ good old firms. In period $2 \bar{q}$ good new firms enter if all new firms restructure. Otherwise there are $\underline{q}$ good new firms.

Proof:

See Appendix.

We find two regions with unique subgame perfect equilibria. For very low (very high) costs of restructuring all old and new firms decide to restructure (not to restructure). In Proposition 3 the unique subgame perfect equilibria are described for the restructuring decision of the new firms' managers when the restructuring behavior of old firms is exogenously given. A comparison between the results of Proposition 3 and 4 gives an intuition for the interdependence of restructuring decisions. In Proposition 4 the new firms have better restructuring incentives when costs are rather low because there is a positive intergenerational externality from the restructuring decision of old firms. In this cost range old firms have better restructuring incentives than new firms since the net present value of the restructuring investment is higher. By opting for restructuring the old firms reduce repayment $R^{2}$ for the new firms in period 2 and thus increase their restructuring incentives. Therefore the parameter range where the new firms restructure increases from $C_{4}$ to $\frac{K_{4}}{1+f}$.

In the following an intuitive explanation for the results of Proposition 4 is provided. There are interdependencies between restructuring decisions in one period (which will be called intragenerational externality) and between periods (which will be called intergenerational externality). In particular, the occurrence of multiple equilibria is studied, where one equilibrium is more desirable from an efficiency point of view than the other. The interdependency of restructuring decisions can be seen for costs at the bottom end of the intermediate range (which is part of case (2)). The existence of multiple equilibria is due to a coordination problem in the second period subgame. The managers of new firms will restructure only if the other new firms intend to restructure. The problem could be solved by coordination. Coordination is furthermore desirable as the managers of old firms want to restructure only if the new firms intend to restructure, and thus the restructuring decision of new firms also determines the outcome of the restructuring game in period 1 . Consequently, coordination in period 2 is needed to get restructuring in both periods.

The coordination problem is even more severe if costs are low or in the middle of the intermediate range, what is part of case (2). Here, the restructuring deci- 
sion in the second period subgame depends on the old firms' restructuring effort, which is observable at the time when the new firms consider restructuring. But if the old firms expect that the new firms do not intend to restructure, they decide not to restructure themselves. This, however, prevents the new firms from restructuring, and the economy ends up with the worst equilibrium (EQ2), without any restructuring.

The opposite direction of the intergenerational externality is also possible, where a coordination problem in period 1 influences corporate restructuring in period 2. In case (3) there is a coordination problem among the old firms. Old firms have an incentive to restructure only if all other old firms intend to restructure. However, if coordination towards restructuring fails in period 1, neither the old nor the new firms will restructure. For the new firm the reason is that the repayment $R^{2}$ is high as there is a high share of bad old firms which apply for credit in period 2. Even if coordination towards restructuring is reached in period 1 , there is an additional coordination problem among the new firms.

In case (2) when the restructuring costs are high, all kinds of coordination problems can be found. The managers of old firms and of new firms have an incentive to restructure if all other old and all other new firms intend to restructure. Thus, there is a coordination problem among the old firms, which determines the decision in the second period: New firms restructure only if old firms have restructured. Additionally, there is a coordination problem among the new firms: New firms restructure only if all other new firms restructure. Again, this carries through to the first period: Old firms want to restructure only if all new firms intend to restructure. To get the result that old as well as new firms restructure, coordination towards restructuring has to be reached in both periods.

\subsection{Multiple equilibria and coordination policy}

The analysis above shows that the interaction between restructuring decisions depends on the restructuring costs. We have characterized the maximum amount of interactions. There will be fewer interdependencies if the structure of restructuring costs in period 1 and 2 is less intertwined. It has been shown that coordination might fail in each period. The coordination problem in one period can also influence the outcome in another period. These coordination problems could be avoided by policy measures, for example by reducing the restructuring costs. In transition countries many impediments have to be overcome before the investment project can be undertaken. A simplification of all theses procedures would substantially contribute to lower the costs. An alternative way to reduce the costs would be to grant subsidies. However, this policy measure would have to be handled with care as one important goal of transition is to reduce state intervention 
into the economy. Through coordination policy the better equilibrium can be reached. The degree to which coordination policy is necessary depends on the cost structures, as we have seen in Proposition 4.

For example, if restructuring costs are low, at the bottom end and in the middle of the intermediate range (which is part of case (2)) coordination among the restructuring decisions of new firms is sufficient to get the equilibrium where all generations restructure. In case (3), when the costs are at the top end of the intermediate range, the managers of old firms have an incentive to restructure if all old firms intend to restructure. The managers of new firms want to restructure if the old firms have restructured and all other new firms intend to restructure. In this case two steps of coordination are desirable. If the old firms have restructured, the new firms may have an incentive to restructure, too. Thus it is necessary to reach coordination among the old firms. But, as each manager of a new firm wants to restructure only if all other new firms intend to restructure, additional coordination is necessary in period 2. If coordination in the second period fails, there will only be restructuring in period 1 but not in period 2 . The same extent of coordination is necessary in case (2) with high restructuring costs. The coordination failure in one period implies a lack of restructuring in both periods. This shows that the coordination failure is even more severe if costs are higher.

\section{Effects of bank insolvency}

\subsection{New firms}

In this paper the fundamental question is addressed, how bank insolvency affects corporate restructuring. In Section 2.2 it was shown that the repayment which the banks demand in period 2 is determined by the average quality of newly applying firms. This implies the following proposition:

Proposition 5. Bank insolvency has a positive effect on the future restructuring incentives, i.e. on the restructuring decision of new firms.

Proof:

See Appendix.

Bank insolvency decreases $R^{2}$ and increases the parameter range with a unique restructuring equilibrium (see Proposition 3, case (1)). At the same time the parameter range where firms do not restructure decreases (see Proposition 3, case (3)). Furthermore it can be shown that a higher degree of instability decreases the parameter range in which firms may opt for restructuring. 
The result that bank insolvency has a positive effect on restructuring may be surprising. The explanation relies on the banks which operate in an environment with asymmetric information, where informational problems cannot be solved by screening or by offering a self-selection contract. However, this difficult environment seems to prevail in transition economies. Banks do not perform all the tasks which are associated with the allocation of credit in a market economy. The task which is relevant in our analysis is the selection of socially efficient projects. We assumed that banks cannot exclude unprofitable firms from receiving finance. This might seem a somewhat strong assumption, but qualitatively the same results obtain as long as banks do not have a perfect screening-technology.

\subsection{Old firms}

Concerning the influence of bank insolvency on corporate investment of old firms two opposing effect interact.

Proposition 6. Bank insolvency has a negative effect on the current restructuring incentives, i.e. on the restructuring decision of old firms, if $\delta^{B}=\delta^{F}$.

\section{Proof:}

See Appendix.

For old firms the derivative of the benefits of restructuring with respect to the degree of bank solvency $w$ is:

$$
=\Delta p_{i}(\underbrace{\delta^{B}\left(R^{2}-I\right)}_{+}+\underbrace{\left(\delta^{B} w-\delta^{F}\right)\left(\frac{\partial\left(R^{2}(p, q)\right)}{\partial w}\right)}_{-}) \lesseqgtr 0
$$

There are two opposing effects of bank insolvency on the restructuring decision of old firms. On the one hand there is the negative effect of a higher repayment $R^{1}$ which the banks have to demand to break even in a more risky environment. This decreases the return of restructuring in the first period. On the other hand bank insolvency decreases the repayment in period 2. This decrease of $R^{2}$ in the second period is weighted with the discount factor $\delta^{F}$, as the payoff has to be discounted. A lower $R^{2}$ increases $R^{1}$, this effect is weighted with $w \delta^{B}$. It seems plausible that $\delta^{F} \geq \delta^{B}$, and therefore concerning the change in $R^{2}$ the positive effect of bank insolvency dominates.

For an overall evaluation the two opposing effects have to be compared. We find that for $\delta^{F}=\delta^{B}$ the effect of bank insolvency on the restructuring behavior is 
negative as the negative effect on $R^{1}$ outweighs the positive effect on $R^{2}$. However, if banks face restrictions on the deficits which they may run in the first period it is plausible that $\delta^{F}>\delta^{B}$. In this case the degree of bank solvency $w$ matters for the result of comparative statics. A higher $w$ puts less weight on the positive effect of bank insolvency on $R^{2}$. In contrast, starting from a higher degree of bank insolvency ( $w$ low enough) bank insolvency can have a positive effect on the restructuring decision of old firms as it decreases the repayment so strongly that the higher repayment in the first period is overcompensated.

So far it has been shown that bank insolvency has opposing effects on the restructuring decisions of old and new firms, respectively. Naturally the question arises: What is the total effect of bank insolvency? When answering this question it has to be taken into account that the actual outcome of the restructuring game depends in many cases on the coordination policy. This is also reflected in the following proposition:

Proposition 7. (1) Suppose there is coordination in each period. If restructuring costs are very high, i.e. $C=C_{1}(\bar{p}, \bar{q})+\varepsilon$, then there exists a positive effect of bank insolvency on corporate restructuring, i.e. an equilibrium in which neither old nor new firms restructure is replaced by one in which old as well as new firms restructure.

(2) Suppose there is no coordination in any period. If restructuring costs are very low, i.e. $C=\frac{K_{4}(\underline{p}, \underline{q})}{1+f}$, then there exists a negative effect of bank insolvency on corporate restructuring, i.e. an equilibrium in which old as well as new firms restructure is replaced by one in which neither old nor new firms restructure.

\section{Proof:}

See Appendix.

If the coordination problem is solved, then all firms restructure as long as restructuring costs are not very high. At the cost boundary between high and very high costs the restructuring decision of new firms changes as they do no longer have an incentive to restructure and this influences the decision of old firms negatively, they no longer have an incentive to restructure. In this case more bank insolvency reduces the repayment in the second period and consequently the cost boundary increases. This means that the new firms now have an incentive to restructure provided all other new firms intend to restructure and the old firms have restructured. According to the assumption the coordination problem among new firms is solved. This gives the old firms an incentive to restructure, and the coordination problem among the old firms is also solved. In equilibrium all 
generations of firms restructure and therefore bank insolvency has a positive effect on corporate restructuring.

The contrary result is obtained if there is no coordination. Under this circumstances old as well as new firms restructure only as long as the restructuring costs are very low. At the boundary between very low and low costs the decision of the old firms is crucial. An increasing probability of bank insolvency decreases the cost boundary for the old firms. For $C=\frac{K_{4}(\underline{p}, \underline{q})}{1+f}$ they now decide not to restructure as there is no coordination. But their decision not to restructure means that new firms no longer have an incentive to restructure, either. In equilibrium neither old nor new firms restructure. Thus bank insolvency influences corporate restructuring negatively if there is no coordination.

\section{Conclusions}

We started this paper with the surprising finding that bank insolvency did not prevent economic growth in transition countries. The reason is not that the corporate and the banking sector are just poorly integrated - banks are in fact the most important financial intermediaries. However, the banks do not perform all tasks they are supposed to, like channeling the funds to the best investment project. To cover this, we developed a model where banks perform the task of asset transformation (deposits into credit) but are not able to perform other tasks, like e.g. estimating credit risks and process information. Based on this poor banking technology we find, contrary to what one might expect, that bank insolvency has some positive influence on corporate restructuring. This positive effect is due to the adverse selection problem. Firms with unprofitable investment projects are rejected by their incumbent bank and reapply for credit at an outside bank in period 2. However, if banks fail, this problem is less severe since firms have to find a new creditor independent of the type of their project.

In our model the banking sector is not very sophisticated. Banks grant credit without screening the projects, and it is impossible to extract information on the profitability of a project by offering a self-selection contract. Besides, the banks cannot use the information which has been generated on a firm by other banks. What would happen if the banking industry possessed a better ability to generate and process information? First, if banks have a better intertemporal information procession but there are still no screening skills, the old firms will find it more difficult to pretend to be a new firm. Banks would sort - maybe not perfectly firms applying for credit in period 2 into two groups: new firms and old firms. The influence of the old firms restructuring behavior on the new firms' restructuring decisions and vice versa will become less important as the degree of intertemporal 
information flows increases. As long as the spill-over of information is not perfect the degree of bank insolvency plays a role.

Empirically, however, there seems to be a low degree of intertemporal information flows for the sector of small and possibly medium-sized firms - even in an environment with good information procession. The reason is that it is easy for firms to reopen their business under a new name if they have failed. Obtaining knowledge of the credit history is even more difficult in transition countries since there exist hardly any information-agencies which collect information on the quality and repayment behavior of firms. In Poland such an agency has been established with help of US-AID. It covers about 15.000 polish firms, which is only a small fraction of debtors (Bonin et al., 1998). Sometimes banking associations exchange information on defaulting customers, but the flow of information is imperfect.

Second, if banks exert screening effort with a perfect technology, all the problems studied in this paper would disappear. The fact that in transition countries the banks are burdened with many bad loans shows that banks either do not screen or do not possess sufficient knowledge and experience to evaluate the projects ex ante (Anderson and Kegels, 1998). Schnitzer (1999a) studies the bank's incentive to invest in costly screening with a perfect technology instead of granting bad loans. Banks have a better incentive to screen if more competitors are informed. However, the more banks are in the market the more likely they may grant bad loans. Broecker (1990) analyzes the effect of an imperfect screening technology on interest rates and assumes that all banks screen as it is costless. He shows that imperfect screening causes a winner's curse problem. A firm which is denied credit by one bank will apply for credit again. However, by this behavior the average quality of the applying firm decreases. The lower the number of banks, the higher the quality of the borrowers and the lower the interest rate.

Using the results of the model and the discussion of the banking technology the following empirical facts can be explained: First, the result that bank insolvency can have a positive effect on firm restructuring could explain why the transition countries were growing despite the banking crises they faced. The model shows that this is the case if restructuring costs are high and the coordination problem is solved. Second, the possible positive effect of bank insolvency is highest when screening is impossible or inefficient. This argumentation supports the claim according to which bank insolvency has worse consequences for better developed economies since we presume that they have a better technology and therefore they face mainly the negative effect. Third, this finding has an interesting policy implications. If we assume that the screening technology improves over time and it is necessary to clean up the banking sector, banks should be forced out of the 
market in the beginning of the reforms. In this case a higher positive effect of bank insolvency can be expected.

Fourth, our model shows exactly where the negative effects of bank insolvency enter. Banks demand a higher interest rate in a riskier environment. The model concentrates on the price effects of bank insolvency but there are other negative effects, especially on the amount of credit granted. Before banks grant credits they have to attract deposits and transform them into credits. If problems in the banking sector become systemic and the depositors lose confidence into the safety of the banking sector, the amount of funds (and/or bank equity) decreases drastically. But then banks have to ration credit and this banking crisis has severe negative effects on corporate restructuring. Thus, the challenge for politicians in transition countries is to tackle the problems associated with bank insolvency in a way that confidence in the banking sector remains. At the same time they have to assure that asset transformation takes still place and therefore they need not delay the cleaning-up of insolvent banks as deposits will be frozen (what happened for example in the Baltics, see Hansson and Tombak, 1999).

The formal analysis has shown that several coordination problems among the firms arise which are transmitted by the financial market. The restructuring decision today may be influenced by the restructuring decision of a past generation of firms, which causes a path-dependent economic development. Expectations also play an important role. On the one hand the expectation on the restructuring behavior of firms of the same generation influences the resulting equilibrium. On the other hand there are the expectations on the restructuring decisions of a future generation of firms. For the current and for future decisions coordination is desirable to reach the better equilibrium with restructuring. However, there is no uniform proposal to which extent coordination is needed. The coordination policy depends crucially on the restructuring costs. 


\section{Appendix}

\subsection{Proof of Proposition 1}

(a) Incumbent banks

A good old firm is indifferent between the incumbent $\left(R^{2 g}\right)$ and an outside bank $\left(R^{\text {out }}\right)$ if: $X-R^{2 g}=X-R^{\text {out }}$. Thus the incumbent bank demands $R^{2 g}=R^{\text {out }}$ and the good old firms stay with the incumbent bank (due to our assumption).

(b) Outside banks

The other old firms, good ones when their incumbent bank became insolvent and all bad ones, have to find a new creditor. When applying in period 2 firms choose between two pure strategies:

(1) show their credit contract to prove that they are old or

(2) pretend to be new firms.

Banks compete in Bertrand fashion and each bank demands

- in case (1) $R^{o}=I \frac{1-p w}{p(1-w)}$; the latter is determined by the bank's zero profit condition:

$$
(1-p)(-I)+p(1-w)\left(R^{o}-I\right)=0 .
$$

- In case (2) an outside bank demands $R^{2}=I \frac{1-\mu p w}{(1-\mu) q+(1-w) \mu p}$ which is determined by:

$$
\left((1-\mu)\left(q R^{2 h}-I\right)+\mu\left((1-w)\left(p R^{2 h}-I\right)+w(1-p)(-I)\right)\right)=0 .
$$

The dominant strategy is to pretend to be a new firm as $R^{o}>R^{2}$

$$
R^{2}-R^{o}=I \frac{(1-\mu)(p-q-p w(1-q))}{p(1-w)((1-\mu) q+(1-w) \mu p)}<0
$$

The denominator is negative for all combinations of $\bar{p}, \underline{p}, \bar{q}, \underline{q}$ (which are introduced in Section 4):

- for $p=q:(-p w(1-q))<0$

- for $\underline{p}, \bar{q}:(\underline{p}-\bar{q}-\underline{p} w(1-\bar{q}))<0$

- for $\overline{\bar{p}}, \underline{q}:(\overline{\bar{p}}-\underline{q}-\bar{p} w(1-\underline{q}))<0$

as we have assumed that $R^{2}>\frac{I}{p}$ which implies that $\bar{q}-\underline{p}-w \underline{p}(1-\underline{p})<0$ and as $\bar{p}=\bar{q}, \underline{p}=\underline{q}$ the expression above is negative, too.

There is no incentive for the banks to deviate from this interest rate, as decreasing the interest rate would lead to an expected loss and increasing the interest rate would mean loosing all customers.

Allowing mixed strategies does not change the result as $R^{o}$ remains the same but $R^{2}$ decreases. Thus the dominant strategy for the old firms is to pretend to be new.

Q.E.D. 


\subsection{Proof of Lemma 1}

We want to show that $R_{1}^{2}(\bar{p}, \bar{q})<R_{2}^{2}(\underline{p}, \bar{q})<R_{3}^{2}(\bar{p}, \underline{q})<R_{4}^{2}(\underline{p}, \underline{q})$

- $R_{1}^{2}(\bar{p}, \bar{q})-R_{2}^{2}(\underline{p}, \bar{q})=$ $\left(I \frac{1-\mu \bar{p} w}{(1-\mu) \bar{q}+(1-w) \mu \bar{p}}\right)-\left(I \frac{1-\mu \underline{p} w}{(1-\mu) \bar{q}+(1-w) \mu \underline{p}}\right)=$ $\left(I \frac{(1-\mu) \mu(\underline{p}-\bar{p})(\bar{q} w+1)}{((1-\mu) \bar{q}+(1-w) \mu \bar{p})((1-\mu) \bar{q}+(1-w) \mu \underline{p})}\right)<0$. Thus $R_{1}^{2}(\bar{p}, \bar{q})<R_{2}^{2}(\underline{p}, \bar{q})$.

- $R_{2}^{2}(\underline{p}, \bar{q})-R_{3}^{2}(\bar{p}, \underline{q})=\left(I \frac{1-\mu \underline{p} w}{(1-\mu) \bar{q}+(1-w) \mu \underline{p}}\right)-\left(I \frac{1-\mu \bar{p} w}{(1-\mu) \underline{q}+(1-w) \mu \bar{p}}\right)$ with $\underline{p}=\underline{q}$ and $\bar{p}=\bar{q}$ and $\mu=0.5$

$\left(I \frac{-(\bar{p}-\underline{p})(0.5 w(-0.5(\bar{p}+\underline{p})+1))}{((1-\mu) \bar{p}+(1-w) \mu \underline{p})((1-\mu) \underline{p}+(1-w) \mu \bar{p})}\right)<0$

as $(-0.5)(\bar{p}+\underline{p})+1>0$ as $\bar{p}<1, \underline{p}<1$. Thus $R_{2}^{2}(\underline{p}, \bar{q})<R_{3}^{2}(\bar{p}, \underline{q})$.

- $R_{3}^{2}(\bar{p}, \underline{q})-R_{4}^{2}(\underline{p}, \underline{q})$

$\left(I \frac{1-\mu \bar{p} w}{(1-\mu) \underline{q}+(1-w) \mu \bar{p}}\right)-\left(I \frac{1-\mu \underline{p} w}{(1-\mu) \underline{q}+(1-w) \mu \underline{p}}\right)=$ $\left(I \frac{(1-\mu) \mu(-\bar{p}+\underline{p})}{((1-\mu) \underline{q}+(1-w) \mu \bar{p})((1-\mu) \underline{q}+(1-w) \mu \underline{p})}\right)<0$. Thus $R_{3}^{2}(\bar{p}, \underline{q})<R_{4}^{2}(\underline{p}, \underline{q})$. Q.E.D.

\subsection{Proof of Proposition 2}

In this two-period model the hold-up problem in period 2 is anticipated. As there is Bertrand competition for the old customers, the incumbent bank makes zero profit out of this two-period relationship with good old borrowers. Banks are liable for their first period loss as they are endowed with equity. The profit of the incumbent bank $g$ in period 2 has to be weighted with the discount factor $\delta^{B}$ and the probability $w$ that the bank survives: ${ }^{10}$

$$
\Pi^{g}=\left(p R^{1}-I\right)+\delta^{B} p w\left(R^{2 g}-I\right)=0
$$

with $R^{1}=\frac{I}{p}-\delta^{B} w\left(R^{2}-I\right)$.

Q.E.D.

\footnotetext{
${ }^{10} \sigma^{B}=\frac{1}{1+r^{B}}$ where $r^{B}$ is the interest rate for the bank.
} 


\subsection{Proof of Proposition 3}

Each manager of a new firm has to decide about restructuring, the individual firm is denoted by $j$. He invests in restructuring if

$$
\begin{aligned}
\bar{q}_{j}\left(X-R^{2}(p, q)\right)-C & \geq \underline{q}_{j}\left(X-R^{2}(p, q)\right) \\
\Delta q_{j}\left(X-R^{2}(p, q)\right) & \geq C
\end{aligned}
$$

Define the critical values of the restructuring costs $C$.

$$
\begin{aligned}
\Delta q_{j}\left(X-R_{1}^{2}(\bar{p}, \bar{q})\right) & =C_{1}(\bar{p}, \bar{q}) \\
\Delta q_{j}\left(X-R_{2}^{2}(\underline{p}, \bar{q})\right) & =C_{2}(\underline{p}, \bar{q}) \\
\Delta q_{j}\left(X-R_{3}^{2}(\bar{p}, \underline{q})\right) & =C_{3}(\bar{p}, \underline{q}) \\
\Delta q_{j}\left(X-R_{4}^{2}(\underline{p}, \underline{q})\right) & =C_{4}(\underline{p}, \underline{q})
\end{aligned}
$$

Given the result of Lemma 1 , that $R_{1}^{2}(\bar{p}, \bar{q})<R_{2}^{2}(\underline{p}, \bar{q})<R_{3}^{2}(\bar{p}, \underline{q})<R_{4}^{2}(\underline{p}, \underline{q})$, the restructuring costs can be ranked as follows: $C_{4}(\underline{p}, \underline{q})<C_{3}(\bar{p}, \underline{q})<C_{2}(\underline{p}, \bar{q})<$ $C_{1}(\bar{p}, \bar{q})$. Depending on the restructuring costs there exist three different outcomes in pure strategies:

(1) If $C \leq C_{4}(\underline{p}, q)$, each manager has an incentive to restructure even if no other firm intends to restructure. As all new firms are identical, there exists a unique equilibrium where all new firms restructure.

(2a) If $C_{4}(\underline{p}, \underline{q})<C \leq C_{3}(\bar{p}, \underline{q})$, each manager has an incentive to restructure provided the old firms have restructured. This share $p$ is observable for the new firm's manager before he decides on restructuring. As a result, there are two equilibria. If the share of good old firms is high $(\bar{p})$, all new firms restructure (equilibrium 1). If the share of good old firms is low $(\underline{p})$, no new firm restructures (equilibrium 2).

(2b) If $C_{3}(\bar{p}, q)<C \leq C_{2}(p, \bar{q})$, each manager has an incentive to restructure provided all other new firms intend to restructure. Thus, in equilibrium 1, all new firms restructure. However, the manager does not have an incentive to restructure if no other new firm intends to restructure. Thus, in equilibrium 2, no new firm restructures.

(2c) If $C_{2}(\underline{p}, \bar{q})<C \leq C_{1}(\bar{p}, \bar{q})$, each manager has an incentive to restructure provided the old firms have restructured and all new firms intend to restructure. There are two equilibria if the old firms have restructured. Each manager prefers to restructure if all other new firms 
want to restructure. Thus, in equilibrium 1, all new firms restructure. However, if each manager expects that no other new firm intends to restructure, he does not restructure, either. Thus, in equilibrium 2, no new firm restructures.

(3) If $C_{1}(\bar{p}, \bar{q})<C$, no manager has an incentive to restructure even if all other firms intend to restructure. As all firms are identical, there exists a unique equilibrium where no firm restructures.

Q.E.D.

\subsection{Proof of Lemma 2}

We want to show that $K_{4}(\underline{p}, \underline{q})<K_{2}(\underline{p}, \bar{q})<K_{3}(\bar{p}, \underline{q})<K_{1}(\bar{p}, \bar{q})$

Like for the new firms we can define the critical values for costs $K$, which determine the restructuring decision.

$$
\begin{aligned}
\Delta p_{i}\left(\left(X-R^{1}(\bar{p}, \bar{q})\right)+\delta^{F}\left(X-R^{2}(\bar{p}, \bar{q})\right)\right) & =(1+f) C_{1}=K_{1} \\
\Delta p_{i}\left(\left(X-R^{1}(\underline{p}, \bar{q})\right)+\delta^{F}\left(X-R^{2}(\underline{p}, \bar{q})\right)\right) & =(1+f) C_{2}=K_{2} \\
\Delta p_{i}\left(\left(X-R^{1}(\bar{p}, \underline{q})\right)+\delta^{F}\left(X-R^{2}(\bar{p}, \underline{q})\right)\right) & =(1+f) C_{3}=K_{3} \\
\Delta p_{i}\left(\left(X-R^{1}(\underline{p}, \underline{q})\right)+\delta^{F}\left(X-R^{2}(\underline{p}, \underline{q})\right)\right) & =(1+f) C_{4}=K_{4}
\end{aligned}
$$

With Lemma 1 we can show that $K_{1}(\bar{p}, \bar{q})>K_{2}(\underline{p}, \bar{q})$ and $K_{3}(\bar{p}, \underline{q})>K_{4}(\underline{p}, \underline{q})$.

$$
\begin{aligned}
& K_{1}(\bar{p}, \bar{q})-K_{2}(\underline{p}, \bar{q}) \\
& \Delta p_{i}(\underbrace{\frac{I}{p}-\frac{I}{\bar{p}}}_{+}+\underbrace{\left(\delta^{F}-w \delta^{B}\right)}_{+} \underbrace{\left(R^{2}(\underline{p}, \bar{q})-R^{2}(\bar{p}, \bar{q})\right)}_{+})>0 .
\end{aligned}
$$

Thus $K_{1}(\bar{p}, \bar{q})>K_{2}(\underline{p}, \bar{q})$.

$$
\begin{aligned}
& K_{3}(\bar{p}, \underline{q})-K_{4}(\underline{p}, \underline{q}) \\
& \Delta p_{i}(\underbrace{\frac{I}{p}-\frac{I}{\bar{p}}}_{+}+\underbrace{\left(\delta^{F}-w \delta^{B}\right)}_{+} \underbrace{\left(R^{2}(\underline{p}, \underline{q})-R^{2}(\bar{p}, \underline{q})\right)}_{+})>0 .
\end{aligned}
$$

Thus $K_{3}(\bar{p}, \underline{q})>K_{4}(\underline{p}, \underline{q})$. 
The relationship of $K_{2}(\underline{p}, \bar{q})$ and $K_{3}(\bar{p}, \underline{q})$ has to be inspected more closely.

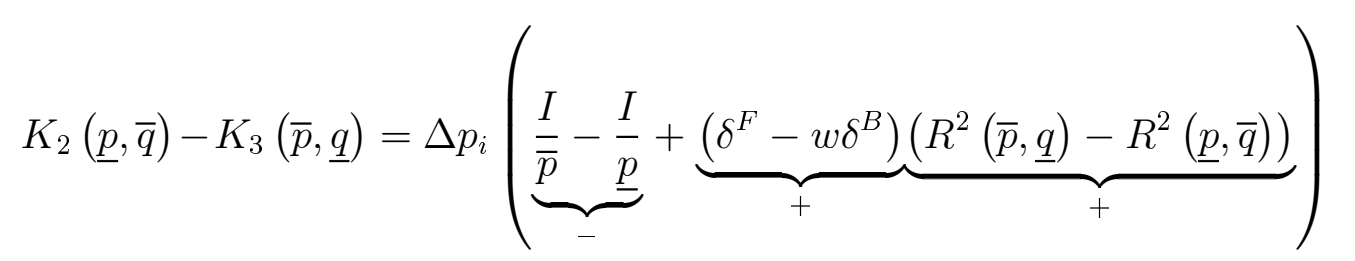

In (6.3) we see that the positive term is multiplied by $\left(\delta^{F}-w \delta^{B}\right) \ll 1$. Thus, the result is that $K_{3}(\bar{p}, \underline{q})>K_{2}(\underline{p}, \bar{q})$ as the positive term of a sum $\left(R^{2}(\bar{p}, \underline{q})-R^{2}(\underline{p}, \bar{q})\right)$ cannot be high enough to compensate for the negative term of a $\operatorname{sum}\left(\frac{I}{\bar{p}}-\frac{I}{\underline{p}}\right)$.

The highest discount factor is $\delta^{F}=\delta^{B}=1$. Then

$\Delta p_{i}\left(\frac{I}{\bar{p}}-\frac{I}{\underline{p}}+(1-w)\left(R^{2}(\bar{p}, \underline{q})-R^{2}(\underline{p}, \bar{q})\right)\right)=$

$\Delta p_{i} I \frac{(1-w)\left((1-w) \bar{p} \underline{p}(\underline{p}-\bar{p})+\left(\underline{p}^{3}-\bar{p}^{3}\right)+w \bar{p} \underline{p}\left(\underline{p}^{2}-\bar{p}^{2}\right)\right)+\bar{p} \underline{p}(\bar{p}-\underline{p}) w(1-2 w)}{\bar{p} \underline{p}(\bar{p}+(1-w) \underline{p})(\underline{p}+(1-w) \bar{p})}<0$ for $w \geq 0.5$ what is plausible.

Even with these parameter values the result is that $K_{3}(\bar{p}, \underline{q})>K_{2}(\underline{p}, \bar{q})$. Q.E.D.

\subsection{Proof of Proposition 4}

1. Comparison of critical $K$ and critical $C$

In the analysis above we have shown that

$$
\begin{aligned}
& K_{1}(\bar{p}, \bar{q})>K_{3}(\bar{p}, \underline{q})>K_{2}(\underline{p}, \bar{q})>K_{4}(\underline{p}, \underline{q}) \text { and } \\
& C_{1}(\bar{p}, \bar{q})>C_{2}(\underline{p}, \bar{q})>C_{3}(\bar{p}, \underline{q})>C_{4}(\underline{p}, \underline{q})
\end{aligned}
$$

Concerning the comparison of $\mathrm{K}$ and $\mathrm{C}$, we know that $K_{l}>C_{l}$ with $l=$ $1,2,3,4$. We assumed that the net present value of one unit of costs invested is higher in period 1 than in period 2. More formally, using $\Delta p_{i}=\Delta q_{j}$ :

$$
\frac{K_{l}}{1+f}-C_{l}=\Delta p_{i}\left(\frac{1}{1+f}\left(\left(X-R_{l}^{1}\right)+\delta^{F}\left(X-R_{l}^{2}\right)\right)-(1+f)\left(X-R_{l}^{2}\right)\right)>0
$$

The reason is that the payoff in the first period is higher than the payoff in the second period $\left(X-R^{1}\right)>\left(X-R^{2}\right)$ as $R^{1}<R^{2}$.

However, the difference between $K_{l}-C_{m}, l \neq m$, might be negative as the payoff of new firms' investment is higher. Here this could be due to a lower 
repayment, $R_{1}^{2}(\bar{p}, \bar{q})<R_{2}^{2}(\underline{p}, \bar{q})$.

$$
\begin{aligned}
& K_{2}(\underline{p}, \bar{q})-C_{1}(\bar{p}, \bar{q})= \\
& \Delta p_{i}\left(\frac { 1 } { 1 + f } \left(\left(X-R^{1}(\underline{p}, \bar{q})\right)+\delta^{F}\left(X-R^{2}(\underline{p}, \bar{q})\right)\right.\right. \\
& \left.-(1+f)\left(X-R^{2}(\bar{p}, \bar{q})\right)\right) \gtreqless 0
\end{aligned}
$$

Now we can compare the different limits for the costs $\left(\frac{K_{l}}{1+f}\right.$ and $\left.C_{l}\right)$, which determine the restructuring decisions. The maximum number of interactions between the restructuring decisions in period 1 and 2 occur if the restructuring costs can be ranked as follows:

$\frac{K_{1}(\bar{p}, \bar{q})}{1+f}>C_{1}(\bar{p}, \bar{q})>\frac{K_{3}(\bar{p}, \underline{q})}{1+f}>\frac{K_{2}(\underline{p}, \bar{q})}{1+f}>C_{2}(\underline{p}, \bar{q})>C_{3}(\underline{p}, \bar{q})>\frac{K_{4}(\underline{p}, \underline{q})}{1+f}>C_{4}(\underline{p}, \underline{q})$

\section{Determination of equilibria}

Depending on the restructuring costs we can distinguish four different outcomes in pure strategies. The resulting equilibria are the same for parameter constellations in (b) and (d).

(a) There is a unique pure strategy subgame perfect equilibrium where all firms restructure.

(a1) If $C \leq C_{4}(\underline{p}, q)$, the managers of each old and of each new firm have an incentive to restructure even if no other firm intends to restructure. Thus, there exists a unique pure strategy subgame perfect equilibrium where old as well as new firms restructure.

(a2) If $C_{4}(\underline{p}, \underline{q})<C \leq \frac{K_{4}(\underline{p}, \underline{q})}{1+f}$, the manager of each old firm has an incentive to restructure even if no other firm intends to restructure. As a result, all old firms restructure. The manager of each new firm has an incentive to restructure only if the old firms have restructured. As it is observable for the new firms' managers that the old firms have restructured, the new firms will also opt for restructuring. Thus, there exists a unique pure strategy subgame perfect equilibrium where all firms restructure.

(b) There are two pure strategy subgame perfect equilibria.

(b1) If $\frac{K_{4}(\underline{p}, \underline{q})}{1+f}<C \leq C_{3}(\bar{p}, \underline{q})$, the manager of each old firm has an incentive to restructure if all new firms intend to restructure. The manager of each new firm wants to restructure if the old firms have restructured. Thus, the manager of each old firm restructures and the new firms have an incentive to restructure, too. In equilibrium 1 
old as well as new firms restructure. However, no manager of an old firm wants to restructure if no new firm intends to restructure. Then, the managers of new firms prefer not to restructure, either. Thus, in equilibrium 2, neither old nor new firms restructure.

(b2) If $C_{3}(\bar{p}, \underline{q})<C \leq C_{2}(\underline{p}, \bar{q})$, the managers of each old and of each new firm have an incentive to restructure if all other new firms intend to restructure. In equilibrium 1 old as well as new firms restructure. However, neither a manager of an old nor of a new firm wants to restructure if the new firms do not intend to restructure. In equilibrium 2 neither old nor new firms restructure.

(b3) If $C_{2}(\underline{p}, \bar{q})<C \leq \frac{K_{2}(\underline{p}, \bar{q})}{1+f}$, the manager of each old firm has an incentive to restructure if the new firms intend to restructure. The manager of each new firm wants to restructure if old firms have restructured and all other new firms intend to restructure. Therefore, all old firms restructure if the new firms intend to restructure. Then the new firms have an incentive to restructure, too. In equilibrium 1 old as well as new firms restructure. However, no manager of an old firm wants to restructure if the new firms do not intend to restructure. Thus, in equilibrium 2, neither old nor new firms restructure.

(c) There are three pure strategy subgame perfect equilibria.

If $\frac{K_{2}(\underline{p}, \bar{q})}{1+f}<C \leq \frac{K_{3}(\bar{p}, \underline{q})}{1+f}$, the manager of each old firm has an incentive to restructure if all other old firms intend to restructure. The manager of each new firm wants to restructure if all other new firms intend to restructure and if the old firms have restructured. Thus, in equilibrium 1, old as well as new firms restructure. However, no manager of a new firm restructures if no other new firm intends to restructure. Therefore, in equilibrium 2, old firms restructure but new firms don't. Finally, no manager of an old firm intends to restructure if no other old firm restructures. As a consequence, the managers of new firms do not want to restructure, either. Thus, in equilibrium 3, neither old nor new firms restructure.

(d) There are two pure strategy subgame perfect equilibria.

If $\frac{K_{3}(\bar{p}, \underline{q})}{1+f}<C \leq C_{1}(\bar{p}, \bar{q})$, the managers of each old firm and of each new firm have an incentive to restructure if all other old and new firms intend to restructure. Thus, in equilibrium 1, old as well as new firms restructure. However, neither the manager of an old nor of a new firm wants to restructure if either no other old or no other new firm 
intends to restructure. Thus, in equilibrium 2, neither old nor new firms restructure.

(e) There is a unique pure strategy subgame perfect equilibrium where no firm restructures.

(e1) $C_{1}(\bar{p}, \bar{q})<C \leq \frac{K_{1}(\bar{p}, \bar{q})}{1+f}$, each manager of an old firm has an incentive to restructure if all other old and new firms intend to restructure. However, no manager of a new firm wants to restructure, even if all other old and new firms restructure. Thus, there exists a unique pure strategy subgame perfect equilibrium where no firm restructures.

(e2) If $\frac{K_{1}(\bar{p}, \bar{q})}{1+f}<C$, neither the manager of an old firm nor of a new firm ever want to restructure even if all other old and new firms restructure. Thus, there exists a unique pure strategy subgame perfect equilibrium where no firm restructures.

Q.E.D.

\subsection{Proof of Proposition 5}

$$
\Delta q_{j}\left(X-R^{2}(p, q)\right) \geq C
$$

For each interest rate the LHS determines the restructuring decision. Comparative statics show that

$$
\begin{aligned}
& \frac{\partial\left[\Delta q_{j}\left(X-R^{2}(p, q)\right)\right]}{\partial w} \\
= & \Delta q_{j}\left(-I \frac{\mu p(1-q+\mu q-\mu p)}{((1-\mu) q+(1-w) \mu p)^{2}}\right)<0
\end{aligned}
$$

The denominator is positive. The nominator is positive because $\mu=0.5$ and $\bar{p}, \bar{q}<1, \underline{p}, \underline{q}<1$ and therefore $(1-0.5 q-0.5 p)>0$ for all combinations of $p$ and $q$.

To show the effect of a change of $w$ on the intermediate cost range where multiple equilibria occur we compare

$$
\begin{aligned}
& \frac{\partial C_{1}}{\partial w}-\frac{\partial C_{4}}{\partial w}=\left[\Delta q_{j}\left(-I \frac{\mu \bar{p}(1-\bar{q}+\mu \bar{q}-\mu \bar{p})}{((1-\mu) \bar{q}+(1-w) \mu \bar{p})^{2}}\right)\right]-\left[\Delta q_{j}\left(-I \frac{\mu \underline{p}(1-\underline{q}+\mu \underline{q}-\mu \underline{p})}{((1-\mu) \underline{q}+(1-w) \mu \underline{p})^{2}}\right)\right]= \\
& \Delta q_{j}\left(I \frac{0.25(2-w)^{2} \bar{p} \underline{p}(\bar{p}-\underline{p})}{(0.5 \bar{q}+(1-w) 0.5 \bar{p})^{2}(0.5 \underline{q}+(1-w) 0.5 \underline{p})^{2}}\right)>0
\end{aligned}
$$

Thus, if $w$ increases, the intermediate range increases as $C_{1}$ decreases by less than $C_{4}$. If $w$ decreases, the intermediate range decreases as $C_{1}$ increases by less than $C_{4}$.

Q.E.D. 


\subsection{Proof of Proposition 6}

For old firms the derivative of the benefits of restructuring with respect to the degree of bank solvency $w$ is:

$$
\begin{gathered}
\frac{\partial\left(\Delta p_{i}\left(X-\frac{I}{p}+\delta^{B} w\left(R^{2}(p, q)-I\right)+\delta^{F}\left(X-R^{2}(p, q)\right)\right)\right)}{\partial w}= \\
\Delta p_{i}(\underbrace{\delta^{B}\left(R^{2}-I\right)}_{+}+\underbrace{\left(\delta^{B} w-\delta^{F}\right)\left(\frac{\partial\left(R^{2}(p, q)\right)}{\partial w}\right)}_{-}) \lesseqgtr 0
\end{gathered}
$$

Generally, the effect of bank insolvency is ambiguous. However, for $\delta^{B}=\delta^{F}$, when banks and firms have the same rate of time preference, we find that the derivative is $I \frac{(1-\mu) q(1-q+\mu q-\mu p)}{((1-\mu) q+(1-w) \mu p)^{2}}>0$.

Q.E.D.

\subsection{Proof of Proposition 7}

(1) Suppose there is coordination in each period. Then there exist two different outcomes depending on the restructuring costs:

(I) There is a unique pure strategy subgame perfect equilibrium where all firms restructure if $C \leq C_{1}(\bar{p}, \bar{q})$.

(II) There is a unique pure strategy subgame perfect equilibrium where no firm restructures if $C>C_{1}(\bar{p}, \bar{q})$.

Now suppose that $C>C_{1}(\bar{p}, \bar{q})+\varepsilon$ (in equilibrium neither old nor new firms restructure) and that the probability of bank insolvency increases. Accordingly the repayment in the second period $R^{2}$ decreases and $C=C_{1}(\bar{p}, \bar{q})$. Then the managers of each old firm and of each new firm have an incentive to restructure if all other old and new firms intend to restructure. As there is coordination old as well as new firms restructure.

(2) Suppose there no coordination in any period. Then there exist two different outcomes depending on the restructuring costs:

(I) There is a unique pure strategy subgame perfect equilibrium where all firms restructure if $C \leq \frac{K_{4}(\underline{p}, \underline{q})}{1+f}$.

(II) There is a unique pure strategy subgame perfect equilibrium where no firm restructures if $C>\frac{K_{4}(\underline{p}, \underline{q})}{1+f}$.

Now suppose that $C=\frac{K_{4}(\underline{p}, \underline{q})}{1+f}$ (in equilibrium old as well as new firms restructure) and that the probability of bank insolvency increases. Accordingly the repayment in the second period $R^{2}$ decreases and the repayment in the first period 
increases $R^{1}$ such that $C>\frac{K_{4}(\underline{p}, \underline{q})}{1+f}$. Then the manager of each old firm has an incentive to restructure if all new firms intend to restructure. The manager of each new firm wants to restructure if the old firms have restructured. However, as there is no coordination, no manager of an old firm wants to restructure if no new firm intends to restructure. Then, the managers of new firms prefer not to restructure, either. Thus in equilibrium neither old nor new firms restructure. Q.E.D. 


\section{References}

Anderson, R.W. and Ch. Kegels, 1998, Transition Banking: Financial Development of Central and Eastern Europe (Oxford University Press, Oxford and New York).

Blommestein, H.J., 1997, Transformation of the Banking Sector in Central and Eastern Europe - Policy Assessment and Next Steps, in: OECD Proceedings, The New Banking Landscape in Central and Eastern Europe: Country Experience and Policies for the Future (OECD, Paris) $17-42$.

Bonin, J.P., K. Miszei, I.P. Székely and P. Wachtel, 1998, Banking in Transition Economies: Developing Market Oriented Banking Sectors in Eastern Europe (Edward Elgar, Cheltenham and Northampton).

Broecker, T., 1990, Credit-Worthiness Tests and Interbank Competition, Econometrica 58, 429 - 452.

Caprio, G. Jr. and D. Klingebiel, 1997, Bank Insolvency: Bad Luck, Bad Policy, or Bad Banking?, in: M. Bruno and B. Pleskovic, eds., Annual World Bank Conference on Development Economics 1996 (The World Bank, Washington, D.C) 79 - 114.

Dell'Ariccia, G., E. Friedman and R. Marquez, 1999, Adverse selection as a barrier to entry in the banking industry, RAND Journal of Economics 30, 515 534 .

EBRD, 1998, Transition Report 1998: Financial Sector in Transition (EBRD, London).

Gorton, G. and A. Winton, 1998, Banking in Transition Economies: Does Efficiency Require Instability?, Journal of Money, Credit, and Banking 30, 621 650 .

Hansson, A.H. and T. Tombak, 1999, Banking Crisis in the Baltic States: Causes, Solutions, and Lessons, in: M.J. Brejer and M. Škreb, Marko, eds., Financial Sector Transformation, Lessons from Economies in Transition (Cambridge University Press, Cambridge, UK) 195 - 236.

Ickes, B. and R. Ryterman, 1994, From Enterprise to Firm: Notes for a Theory of the Enterprise in Transition, in: R.W. Campbell, ed., The Postcommunist Economic Transformation: Essays in Honor of Gregory Grossman (Westview Press, Boulder, CO) 83 - 104.

Schnitzer, M., 1999a, On the Role of Bank Competition for Corporate Finance and Corporate Control in Transition Economies, Journal of Institutional and Theoretical Economics 155, 23-50. 
Schnitzer, M., 1999b, Bank competition and enterprise restructuring in transition economies, Economics of Transition 7, 133 - 155.

Sharpe, S.A., 1990, Asymmetric Information, Bank Lending, and Implicit Contracts: A Stylized Model of Customer Relationships, Journal of Finance 45, 1069 $-1087$.

Stiglitz, J.E. and A. Weiss, 1981, Credit Rationing in Markets with Imperfect Information, American Economic Review 71, 393 - 410. 


\section{DAVIDSON INSTITUTE WORKING PAPER SERIES - Most Recent Papers}

The entire Working Paper Series is available at: www.wdi.bus.umich.edu

CURRENT AS OF 10/4/01

\begin{tabular}{|c|c|c|}
\hline Publication & Authors & Date \\
\hline $\begin{array}{l}\text { No. 390: Effects of Bank Insolvency and Strategic Uncertainty on } \\
\text { Corporate Restructuring in Transition Economies }\end{array}$ & Christa Hainz & Aug. 2001 \\
\hline No. 389: Mark-Up Pricing In Bulgarian Manufacturing & \begin{tabular}{|l|} 
Rumen Dobrinsky, Boyko \\
Nikolov, and Nikolay Markov
\end{tabular} & June 2001 \\
\hline $\begin{array}{l}\text { No. } 388 \text { Globalization and Firms' Financing Choices: } \\
\text { Evidence from Emerging Economies }\end{array}$ & $\begin{array}{l}\text { Sergio Schmukler and Esteban } \\
\text { Vesperoni }\end{array}$ & May 2001 \\
\hline $\begin{array}{l}\text { No. } 387 \text { The Distributional Impacts of Indonesia's Financial Crisis on } \\
\text { Household Welfare: A "Rapid Response" Methodology }\end{array}$ & $\begin{array}{l}\text { Jed Friedman and James } \\
\text { Levinsohn }\end{array}$ & Sept. 2001 \\
\hline $\begin{array}{l}\text { No. } 386 \text { Corporate Financial Policies and Performance Prior to Currency } \\
\text { Crises }\end{array}$ & $\begin{array}{l}\text { Arturo Bris, Yrjö Koskinen, and } \\
\text { Vicente Pons }\end{array}$ & June 2001 \\
\hline No. 385 Ownership and Productive Efficiency: Evidence from Estonia & Derek C. Jones and Niels Mygind & Aug. 2001 \\
\hline $\begin{array}{l}\text { No. } 384 \text { Forthcoming in: Journal of Economic Perspectives, } \\
\text { "Institutional Determinants of Labor Reallocation in Transition" Vol. } \\
\text { 16, No. 2, Feb. } 2002 \text {. }\end{array}$ & Tito Boeri and Katherine Terrell & June 2001 \\
\hline $\begin{array}{l}\text { No. } 383 \text { Deindustrialisation and Structural Change During the Post- } \\
\text { Communist Transition }\end{array}$ & $\begin{array}{l}\text { Tomasz Mickiewicz and Anna } \\
\text { Zalewska }\end{array}$ & June 2001 \\
\hline No. 382 Markets and Growth & Štěpán Jurajda and Janet Mitchell & July 2001 \\
\hline $\begin{array}{l}\text { No. } 381 \text { Labor Market Discrimination During Post-Communist } \\
\text { Transition: A Monopsony Approach to the Status of Latvia's Russian } \\
\text { Minority }\end{array}$ & Robert S. Chase & Sept. 2000 \\
\hline No. 380 Dollarization of Liabilities in Non-tradable Goods Sector & Frédéric Chabellard & June 2001 \\
\hline $\begin{array}{l}\text { No. } 379 \text { Lessons from the Russian Meltdown: The Economics of Soft } \\
\text { Legal Constraints }\end{array}$ & Enrico Perotti & Mar. 2001 \\
\hline No. 378 Effective Tax Rates in Transition & Vlad Iva & May 2001 \\
\hline $\begin{array}{l}\text { No. } 377 \text { Some Explanations for Changes in the Distribution of } \\
\text { Household Income in Slovakia: } 1988 \text { and } 1996\end{array}$ & $\begin{array}{l}\text { Thesia Garner and Katherine } \\
\text { Terrell }\end{array}$ & May 2001 \\
\hline $\begin{array}{l}\text { No. } 376 \text { Competition and Enterprise Performance in Transition } \\
\text { Economies: Evidence from a Cross-country Survey }\end{array}$ & \begin{tabular}{|l} 
Wendy Carlin, Steven Fries, \\
Mark Schaffer and Paul Seabright \\
\end{tabular} & May 2001 \\
\hline $\begin{array}{l}\text { No. } 375 \text { Why More is Actually Less: New Interpretations of China's } \\
\text { Labor-Intensive FDI }\end{array}$ & Yasheng Huang & May 2001 \\
\hline No. 374 Economic Fragmentation and FDI in China & ng Huang & May 2001 \\
\hline $\begin{array}{l}\text { No. } 373 \text { Earnings Disparities in the Czech Republic: Evidence of the } \\
\text { Past Decade and Cross-National Comparison }\end{array}$ & Jiri Vecernik & May 2001 \\
\hline $\begin{array}{l}\text { No. } 372 \text { Economic Reform, Democracy and Growth During Post- } \\
\text { Communist Transition }\end{array}$ & Jan Fidrmuc & Mar. 2001 \\
\hline $\begin{array}{l}\text { No. } 371 \text { Do Multinational Enterprises Substitute Parent Jobs for Foreign } \\
\text { Ones? Evidence from Firm Level Panel Data }\end{array}$ & Jozef Konings and Alan Murphye & Apr. 2001 \\
\hline $\begin{array}{l}\text { No. } 370 \text { From Needs to the Market: Changing Inequality of Household } \\
\text { Income in the Czech Transition }\end{array}$ & Jiri Vecernik & Apr. 2001 \\
\hline $\begin{array}{l}\text { No. } 369 \text { Competition and Corporate Governance: Substitutes or } \\
\text { Complements? Evidence from the Warsaw Stock Exchange }\end{array}$ & $\begin{array}{l}\text { Irena Grosfeld and Thierry } \\
\text { Tressel }\end{array}$ & Mar. 2001 \\
\hline $\begin{array}{l}\text { No. } 368 \text { Multinational Corporations as Catalyst for Industrial } \\
\text { Development: The Case of Poland }\end{array}$ & $\begin{array}{l}\text { Carlo Altomonte and Laura } \\
\text { Resmini }\end{array}$ & Feb. 2001 \\
\hline No. 367 A Multi-Task Theory of the State Enterprise Reform & \begin{tabular}{|l|} 
Chong-En Bai, David D. Li, \\
Zhigang Tao, and Yijiang Wang \\
\end{tabular} & Mar. 2001 \\
\hline No. 366a Confidence Building in Emerging Stock Markets & Enrico C. Perotti and Luc Laeven & June 2001 \\
\hline No. 366 Confidence Building in Emerging Stock Markets & $\begin{array}{l}\text { Enrico C. Perotti, Luc Laeven, } \\
\text { and Pieter van Oijen }\end{array}$ & Dec. 2000 \\
\hline $\begin{array}{l}\text { No. } 365 \text { Incentive Contracting versus Ownership Reforms: Evidence } \\
\text { from China's Township and Village Enterprises }\end{array}$ & $\begin{array}{l}\text { Chun Chang, Brian McCall, and } \\
\text { Yijang Wang }\end{array}$ & Nov. 2000 \\
\hline
\end{tabular}

